\title{
Sub-Acute Toxicity Study of Ethanol Leaf Extract of Terminalia Chebula On Brain, Stomach and Spleen of Wister Rats
}

\author{
Joseph Oyepata Simeon ${ }^{1 *}$, Builders Modupe ${ }^{1}$, Isinkaye Deborah $\mathbf{R}^{1}$, Sabastine Aliyu Zubairu' \\ Musa Tabitha Lubo ${ }^{3}$, Oyepata j Philip ${ }^{4}$, Joseph Opeyemi Tosin ${ }^{1}$ and Wazis Chama Haruna ${ }^{1}$ \\ ${ }^{1}$ Department of Pharmacology, Bingham University, Nigeria
}

${ }^{2}$ Department of Pharmacology and Therapeutics, Gombe State University, Nigeria.

${ }^{3}$ Department of Pharmacology, Gombe State University, Nigeria

${ }^{4}$ Department of Pharmacology, University of Port Harcourt, Nigeria

*Corresponding author: Joseph Oyepata Simeon, Department of Pharmacology, Faculty of Pharmacy, Bingham University, Nasarawa, Nigeria.

To Cite This Article: Joseph Oyepata Simeon. Sub-Acute Toxicity Study of Ethanol Leaf Extract of Terminalia Chebula On Brain, Stomach and Spleen of Wister Rats. Am J Biomed Sci \& Res. 2019 - 3(3). AJBSR.MS.ID.000677. DOI: 10.34297/AJBSR.2019.03.000677

Received: May 30, 2019 | Published: June 13, 2019

\begin{abstract}
Introduction/Aim: The incidences of medicinal plant toxicity in the society are becoming serious in the society. There is the need for scientist to determine the toxicity profile of most is therefore very important. Terminalia Chebula is traditionally is found in natural colon cleansers and used in treatment of constipation, digestive disorders, irregular fevers, flatulence, ulcers, vomiting, colic, and hemorrhoids. In this study the effect of subacute administration of Terminalia Chebula on the brain, spleen, and stomach were evaluated.
\end{abstract}

Method: Rats of either sex were selected. Group 1 received distilled water $(10 \mathrm{ml} / \mathrm{kg})$, while group 2, 3 and 4 received Terminalia Chebula 200,400 and $800 \mathrm{mg} / \mathrm{kg}$ respectively. Animals were kept in standard cages and given access to the extract, water and food orally for 28 days, after which they were weighed and sacrificed. Blood was collected by cardiac puncture and taken immediately for hematological and chemo pathological analysis. The brain, spleen, and stomach were also harvested for histological study of the effect of the plant using haematotoxylin and eosin (H\&E) staining technique.

Result: There was Significant $(\mathrm{P}<0.05)$ decrease in $\mathrm{RBC}, \mathrm{HGB}, \mathrm{MCV}$, while there was no change in the level of neutrophiles, basophiles, eosinophiles and platelets. The size of the brain, spleen and stomach were observed to be slightly significantly $(\mathrm{p}<0.05)$ increased in rats with dose level of $400 \mathrm{mg} / \mathrm{kg}$, while there was no significant $(\mathrm{p}<0.05)$ change observed at the 200 and $800 \mathrm{mg} / \mathrm{kg}$ dose. Histopathological examination of the brain and stomach showed normal features at all doses. The spleen showed Slight lymphocyte hyperplasia at all doses and normal features at the control $(10 \mathrm{ml} / \mathrm{kg})$.

Conclusion: Result of the study suggests that care should be observed when taken this herb.

Keywords: Rat; Terminalia Chebula; Brain; Stomach

Introduction

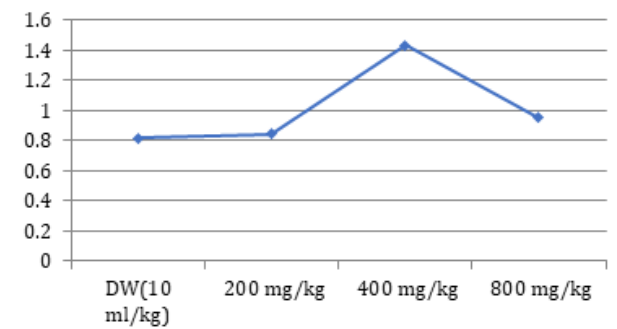

Figure 1: showing effect of Terminalia chebula on the brain body weight ratio. 
The human brain is the body's control center, receiving and sending signals to other organs through the nervous system and through secreted hormones [1]. It is responsible for our thoughts, feelings, memory storage and general perception of the world. The stomach secretes acid and enzymes that digest food. Ridges of muscle tissue called rugae line the stomach. The stomach muscles contract periodically, churning food to enhance digestion. The pyloric sphincter is a muscular valve that opens to allow food to pass from the stomach to the small intestine [2]. The spleen is the largest organ in the lymphatic system. It is an important organ for keeping bodily fluids balanced, but it is possible to live without it [3] (Figure 1).

The spleen is located under the ribcage and above the stomach in the left upper quadrant of the abdomen [4]. A spleen is soft and generally looks purple. It is made up of two different types of tissue. The red pulp tissue filters the blood and gets rid of old or damaged red blood cells. The white pulp tissue consists of immune cells (T cells and B cells) and helps the immune system fight infection. The degree of the toxic effect is not the same in all organs of the body because drugs are distributed differently across body tissue [5]. Usually there are one or two organs which show the major toxic effect. These are referred as target organs of toxicity of the particular substance. It is therefore important to determine the safety and toxicity of plant drugs in different body part. Subacute toxicity tests are intended to evaluate the toxicity of the chemical after repeated administration and also to help in establishing doses for the longer-term subchronic studies [5]. Terminalia chebula tree is about 50-80 feet tall in height [6]. It has round crown and spreading branches. The bark is dark brown with some longitudinal cracks. Leaves are ovate and elliptical, with two large glands at the top of the petiole. The flowers are monoecious, dull white to yellow, with a strong unpleasant odour, borne in terminal spikes or short panicles. T. chebula is found in the Sub Himalayan tracks from Ravi eastwards to West Bengal and Assam, ascending up to the altitude of $1500 \mathrm{~m}$ in the Himalayas (Figure 2).

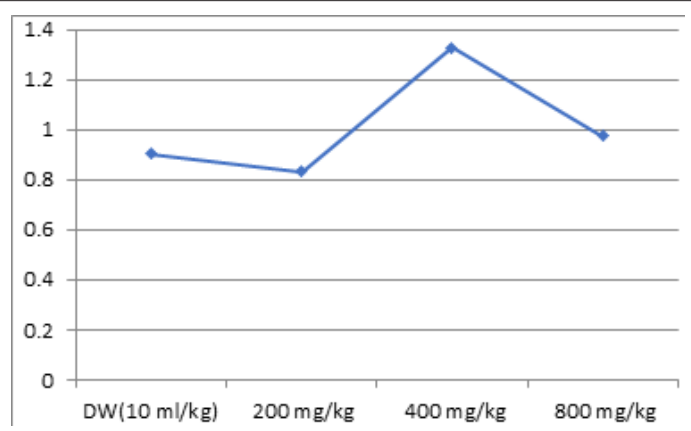

Figure 2: Effect of Terminalia chebula on rat stomach body weight rate ratio.

This tree is wild in forests of Northern India, central provinces and Bengal [7]. The tree is also spread across Africa. The fruit is mild laxative, stomachic, tonic, alterative, antispasmodic [7,8]. It is useful in ophthalmic, hemorrhoids, dental caries, bleeding gums, ulcered oral cavity. Its paste with water is found to be anti-inflammatory, analgesic and having purifying and healing capacity for wounds. Its decoction is used as gargle in oral ulcers, sore throat. Its powder is a good astringent dentifrice in loose gums, bleeding and ulceration in gums [9]. It is good to increase appetite, digestive aid, liver stimulant, stomachic, gastrointestinal prokinetic agent, and mild laxative. The powder of T. chebula fruits has been used in chronic diarrhea. It is used in nervous weakness, nervous irritability. It promotes the receiving power of five senses. It is adjuvant in hemorrhages due to its astringent nature and good for chronic cough, chorizo, sore throat as well as asthma. Also it is useful in renal calculi, dysurea, retention of urine and skin disorders with discharges like allergies, urticaria and other erythematous disorders. Because of the wide use of this plant, the aim of this study is to evaluate the sub-acute toxic effect of the ethanol leaf extract of Terminalia chebula on brain, stomach and spleen of Wister rats [7-9] (Figure 3).

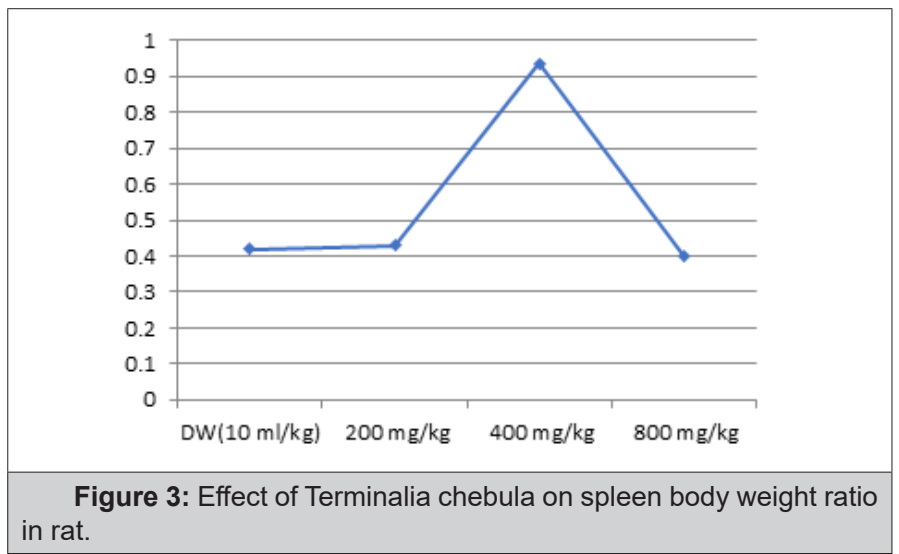

\section{Materials and Method}

\section{Animals}

Male and female Wister rats were obtained from Bingham University, Animal House. They were maintained on standard animal pellets and given water ad libitum. Permission and approval for animal studies were obtained from the College of Health Sciences Animal Ethics Committee of Bingham University.

\section{Plant collection}

Fresh leaves of Terminalia chebula were collected from its natural habitat from nearby Karu village, Nasarawa State, Nigeria. The plant was authenticated from Department of Botany, Bingham University, Nasarawa State, Nigeria.

\section{Plant extraction}

The leaves were shadow dried for two weeks. The dried plant material was further reduced into small pieces and pulverized. The powdered material was macerated in $70 \%$ ethanol. The liquid filtrates were concentrated and evaporated to dryness at $40^{\circ} \mathrm{C}$ in vacuum using rotary evaporator. The ethanol extract was stored at $-4^{\circ} \mathrm{C}$ until used.

\section{Animal study}

Twenty four (24) rats of either sex (125-300g) were selected and randomized into four groups of six rats per group. Group 1 served as the control and received normal saline $(10 \mathrm{ml} / \mathrm{kg})$ while the rats in groups 2, 3 and 4 were giving 200,400 , and $800 \mathrm{mg} / \mathrm{kg}$ of extract respectively. The weights of the rats were recorded at the beginning of the experiment and at weekly intervals. The first day 
of dosing was taken as D0 while the day of sacrifice was designated as D29.

\section{Haematological analysis}

The rats were sacrificed on the 29th day of experiment. Blood samples were collected via cardiac puncture. The blood was collected into sample bottles containing EDTA for hematological analysis such as Hemoglobin concentration, white blood cell counts (WBC), differentials (neutrophils, eosinophils, basophils, lymphocyte and monocyte), red blood cell count (RBC), platelets and hemoglobin $(\mathrm{Hb})$ concentration using automated Haematology machine (Cell-Dyn, Abbott, USA).

\section{Food and water consumption}

The amounts of feed and water consumed were measured daily as the difference between the quantity of feed and water supplied each day and the amount remaining after 24hours. The rats were sacrificed on the 29th day of experiment organs were harvested for further gross histo-pathological analysis (Figure 4).

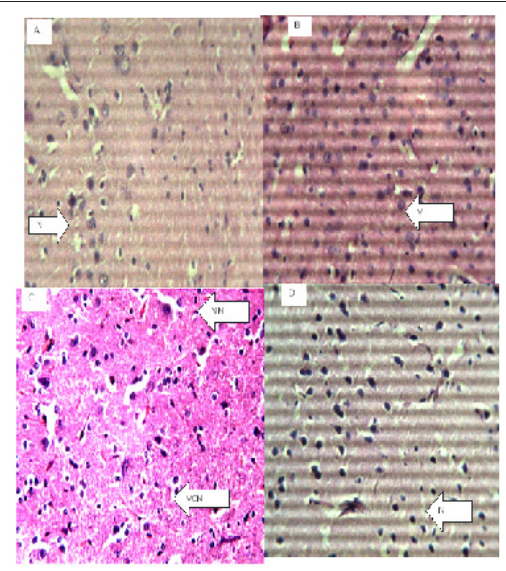

Figure 4: Figure of the brain (Hematoxylin and eosin. $\mathrm{H}$ and $\mathrm{E} \times 100$ ). (a) Control group, Shows normal neurons (N). (b) $200 \mathrm{mg} / \mathrm{kg}$. (c) $400 \mathrm{mg} /$ $\mathrm{kg}$ (d) $800 \mathrm{mg} / \mathrm{kg}$ of ethanol stem extract of Terminalia chebula.

\section{Statistical analysis}

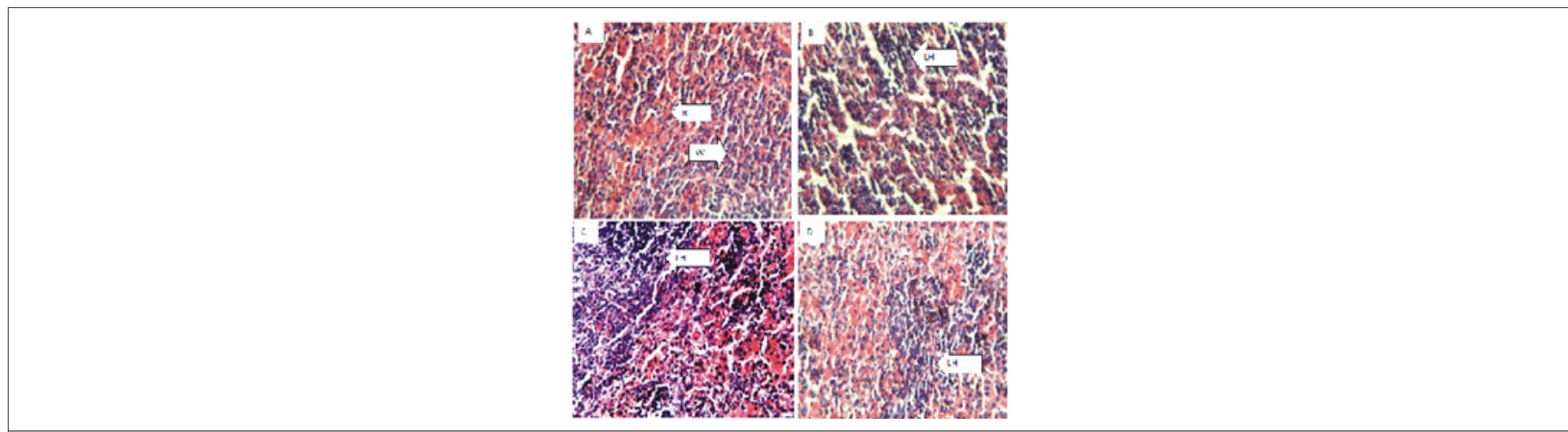

Figure 5: Figure of the Stomach (Hematoxylin and eosin. $\mathrm{H}$ and $\mathrm{E} \times 100$ ). (a) control group, shows normal red (R) and white (W) pulp. (b) 200 $\mathrm{mg} / \mathrm{kg}$ (c) $400 \mathrm{mg} / \mathrm{kg}$, (d) $800 \mathrm{mg} / \mathrm{kg}$ of ethanol leaf extract of Terminalia chebula.

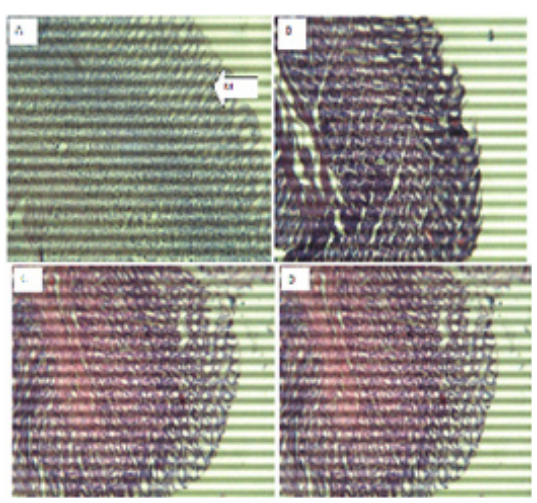

Figure 6: Figure of Spleen (Hematoxylin and eosin. $\mathrm{H}$ and $\mathrm{E} \times 100$ ). (a) Control group, shows normal stomach mucosa (M). (b) $200 \mathrm{mg} / \mathrm{kg}$, shows normal features. (c) $400 \mathrm{mg} / \mathrm{kg}$, shows normal features. (d) $800 \mathrm{mg} / \mathrm{kg}$, shows normal features. 
Data were expressed as the Mean \pm Standard Error of the Mean (SEM). Data were analyzed statistically using one-way Analysis of Variance (ANOVA) followed by Dunnett's post hoc test for multiple

Result comparisons between the control and treated groups. Values of $\mathrm{P} \leq$ 0.05 were considered significant (Figure 5\&6).

Effect of 28 days oral administration of Terminalia chebula on hematological parameters in rats

\begin{tabular}{|c|c|c|c|c|}
\hline \multicolumn{5}{|c|}{ Treatment (mg/kg) } \\
\hline Hematological parameters & DW (10ml/kg) & $200 \mathrm{mg} / \mathrm{kg}$ & $400 \mathrm{mg} / \mathrm{kg}$ & $800 \mathrm{mg} / \mathrm{kg}$ \\
\hline WBC $(\times 109 / \mathrm{L})$ & $9.166 \pm 0.772$ & $7.640 \pm 1.429$ & $4.700 \pm 0.556^{*}$ & $8.230 \pm 1.088$ \\
\hline $\mathrm{RBC}(\times 1012 / \mathrm{L})$ & $9.23 \pm 0.32$ & $9.65 \pm 0.67$ & $7.11 \pm 0.75^{*}$ & $7.81 \pm 0.22$ \\
\hline HGB (g/dL) & $15.56 \pm 0.56$ & $15.45 \pm 0.88$ & $12.33 \pm 0.76^{*}$ & $15.58 \pm 0.37$ \\
\hline HCT (g/dL) & $57.18 \pm 2.03$ & $57.60 \pm 3.75$ & $35.67 \pm 3.18^{*}$ & $54.40 \pm 1.82$ \\
\hline $\operatorname{MCV}(\mathrm{fL})$ & $66.45 \pm 0.93$ & $64.40 \pm 1.14$ & $57.77 \pm 0.31 *$ & $69.61 \pm 1.73$ \\
\hline MCH (pg) & $19.17 \pm 0.17$ & $17.80 \pm 1.02$ & $18.83 \pm 0.37$ & $18.80 \pm 0.20$ \\
\hline $\mathrm{MCHC}(\mathrm{g} / \mathrm{dL})$ & $29.17 \pm 0.17$ & $27.40 \pm 1.12$ & $32.50 \pm 0.62^{*}$ & $27.60 \pm 0.68$ \\
\hline PLT $(\times 109 / \mathrm{L})$ & $620.83 \pm 52.81$ & $567.00 \pm 96.41$ & $252.00 \pm 50.38^{*}$ & $670.40 \pm 55.72$ \\
\hline LYM (\%) & $86.83 \pm 4.06$ & $85.00 \pm 4.18$ & $82.83 \pm 5.89$ & $86.40 \pm 3.14$ \\
\hline NEUT $(\times 109 / \mathrm{L})$ & $11.83 \pm 3.68$ & $11.83 \pm 3.58$ & $14.40 \pm 5.20$ & $13.20 \pm 3.11$ \\
\hline EOSI $(\times 109 / \mathrm{L})$ & $1.53 \pm 0.34$ & $1.40 \pm 0.76$ & $1.90 \pm 0.22$ & $1.40 \pm 0.43$ \\
\hline BASO $(\times 109 / \mathrm{L})$ & $1.10 \pm 0.28$ & $2.45 \pm 0.43$ & $2.50 \pm 1.50$ & $3.40 \pm 2.23$ \\
\hline
\end{tabular}

Data presented as Mean \pm SEM: $n=6$, One way ANOVA, followed by Dunnett's post hoc for multiple comparison *significantly different from the distilled water (DW) control at $p<0.05$. DW: Distilled Water

(WBC: White Blood Cells; RBC: Red Blood Cells; HGB: Hemoglobin; HCT: Hematocrit; MCV: Mean Corpuscular Volume; MCH: Mean Corpuscular Hemoglobin; MCHC: Mean Corpuscular Hemoglobin Concentration; PLT: Platelet; LYM: Lymphocyte; NEUT: Neutrophils; EOSI: Eosinophils; BASO: Basophils).

Terminalia chebula caused significant $(\mathrm{p}<0.05)$ decrease in the level of red blood cell, hemoglobin, platelet etc. and significantly $(\mathrm{p}<0.05)$ caused an increase in mean corpuscular hemoglobin concentration in the rats at the dose level of $400 \mathrm{mg} / \mathrm{kg}$ compared to the control. The level of basophiles, neutrophiles, eosinophils and lymphocytes were however not significantly $(\mathrm{p}<0.05)$ affected by mean corpuscular hemoglobin concentration (Table 1).

\section{Effect of 28 days oral administration of Ocimum canum on body weight (g) in rats}

In the 1 st, 3 rd and 4 th week significant $(p<0.05)$ increase was observed at $200 \mathrm{mg} / \mathrm{kg}$ dose level by ethanol leaf extract of Terminalia chebula, while in the 2nd week there was increase in body weight by the extract but not significant when compared with the control (Table 2).

Table 2: Effect of 28 days oral administration of Ocimum canum on body weight $(\mathrm{g})$ in rats.

\begin{tabular}{|c|c|c|c|c|}
\hline Treatment (mg/kg) & Week 1 & Week 2 & Week 3 & Week 4 \\
\hline DW $(10 \mathrm{ml} / \mathrm{kg})$ & $201.85 \pm 6.71$ & $206.10 \pm 6.35$ & $214.75 \pm 7.30$ & $204.72 \pm 9.74$ \\
\hline $200 \mathrm{mg} / \mathrm{kg}$ & $198.33 \pm 10.17$ & $186.38 \pm 15.58$ & $191.98 \pm 6.42$ & $168.60 \pm 9.64$ \\
\hline $400 \mathrm{mg} / \mathrm{kg}$ & $226.27 \pm 19.51^{*}$ & $238.68 \pm 19.56$ & $234.83 \pm 20.54^{*}$ & $242.83 \pm 20.44^{*}$ \\
\hline $800 \mathrm{mg} / \mathrm{kg}$ & $178.68 \pm 11.39$ & $158.48 \pm 8.94$ & $178.47 \pm 9.57$ & $169.54 \pm 8.30$ \\
\hline
\end{tabular}

Effect of 28 days oral administration of Terminalia chebula on relative organ to body weight ratio in rats

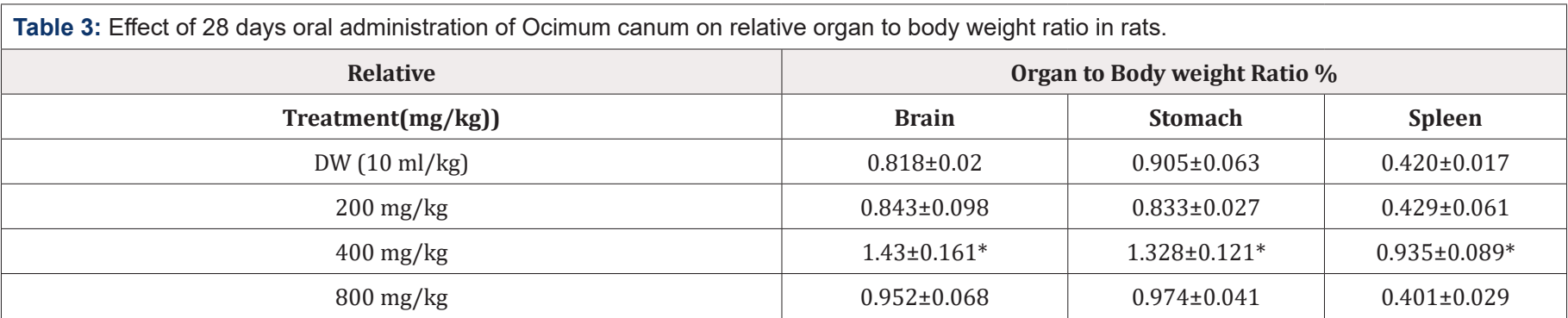


The brain, spleen and stomach were observed to be significantly $(\mathrm{p}<0.05)$ increased in rats with dose level of $200 \mathrm{mg} / \mathrm{kg}$ of the ethanol plant extract. At higher doses of 400 and $800 \mathrm{mg} / \mathrm{kg}$ there was no significant $(\mathrm{p}<0.05)$ change (Table 3$)$.

\section{Effect of oral administration of ethanol leaf extract of Terminalia chebula on histology of Brain, Lungs, Spleen and Stomach of rats}

Histopathological examination of the brain showed normal features at all doses and slight vacuolation at $400 \mathrm{mg} / \mathrm{kg}$ dose of the extract. The lungs showed normal features at all doses respectively. The spleen showed Slight lymphocyte hyperplasia at all doses and normal features at the control $(10 \mathrm{ml} / \mathrm{kg})$. The stomach showed normal features at all doses of the extract administered.

\section{Discussion}

Herbal medicine is becoming popular particularly in developing counties and there is an increased interest in green medicine simply because it is considered safe relative to conventional medicines [10-12]. Traditionally, plants and plant extracts were used to cure many diseases and disorders. However, before usage it is of utmost important to ensure its safety $[13,14]$. The extract may be therapeutically very efficient but if its toxicity assessment is not worked out, it will not be accepted. Hence, toxicity assessment of plants with proven therapeutic use is of utmost important [13]. Toxicity data are required to predict the safety associated before the use of medical products [13-15].

Hematological parameters are useful indices that can be employed to assess the toxic potentials of plant extracts in living systems $[16,17]$. They can also be used to explain blood relating functions of chemical compound/plant extract. Present result showed that ethanol leaf extract of Terminalia chebula caused a reduction in the level of red blood cells, hemoglobin, hematocrit, mean corpuscular volume, mean corpuscular hemoglobin and mean corpuscular hemoglobin concentration which means that it can significantly reduce oxygen carrying capacity of the blood and thus cause anemia. Anemia is a condition where the blood has insufficient red blood cells to carry oxygen from the lungs to the rest of the body or not enough hemoglobin [18-20] the iron-rich protein that carries oxygen inside the red blood cells and gives blood its red color [21-24]. Anemia takes several forms and may vary in severity and duration [22,24]. Also reductions in packed cell volume (PCV) and red blood cell (RBC) were also observed in rats administered with the extract. This implies that Terminalia chebula could cause disturbances in osmoregulatory system of the blood cells and/or oxidative injury to the cell membrane. The extract could suppress the haemopoietic system. The reduction may have also occurred due to lysis of blood cells. Sule et al. [25] also observed decrease in RBC, PCV, hemoglobin and lymphocytes in rats fed with extracts of Acalypha wilkesiana. The major functions of the white blood cell and its differentials are to fight infections, defend the body by phagocytocis against invasion by foreign organisms and to produce or at least transport and distribute antibodies in immune response [26]. The extract had no effect on white blood cell parameters, suggesting that it does not disturb or improve immune system. In this study, there was significant increase in the mean body weight ratio of brain, stomach and spleen of Wister rats administered with ethanol leaf extract of Terminalia chebula at $400 \mathrm{mg} / \mathrm{kg}$ dose below and beyond which there was no effect. The probable reason could be that the plant extract has some toxicity effects on these organs which tend to increase their sizes. This may also suggest that the plant may have a biphasic tendency. That is, at a particular dose it has an oxidant effect, while at higher dose it may be reversed or act as an antioxidant. In addition, reports indicated that tannins, saponins, volatile oils, saponin glycosides and alkaloids were detected in fresh and dried samples of Terminalia chebula [19,2628]. Histology observation also agrees with other parameters that the plant extract may be deleterious at some doses while at other doses, the plant may be safe.

\section{Conclusion}

Though, biochemical analysis was not carried out in this work, result suggests the need for caution while consuming the plant. It is also important to establish the right dose that will be beneficial for the purpose intended. Further work that will include biochemical study may be done to give a better and broader insight on the possible activity of Terminalia chebula in the body.

\section{Acknowledgement}

The authors will like to thank everyone who has assisted in the successful outcome of this work

\section{References}

1. Lennox James (2017) Aristotle's Biology. Plato. Stanford University. Retrieved 23. Section 2: Aristotle's Philosophy of Science. pp. 27-32.

2. Philip Ball, The Devil's Doctor: Paracelsus and the World of Renaissance Magic and Science. pp. 321-327.

3. Engelking Carl (2017) We got the mesentery news all wrong. The Crux p. $43-50$.

4. Coffey J Calvin, O'Leary D Peter (2016) The mesentery: structure, function, and role in disease. Lancet Gastroenterol Hepatol 1(3): 238247.

5. Griffith Oliver W, Wagner Ginter P (2017) The placenta as a model for understanding the origin and evolution of vertebrate organs. Nature Ecology \& Evolution 1(4): 0072.

6. Zhang X, Chen C, He S, Ge F (1997) Supercritical-CO2 fluid extraction of the fatty oil in Terminalia chebula and GC-MS analysis. Zhong Yao Cai 20(9): 463-464.

7. Mammen D, Bapat S, Sane R (2012) An investigation to variation in constituents in the fruits of Terminalia chebula Retz. at different maturity stages. Int J Pharm Bio Sci 3(1):416-419.

8. Han Q, Song J, Qiao C, Wong L, Xu H (2006) Preparative isolation of hydrolysable tannins chebulagic acid and chebulinic acid from Terminalia chebula by high-speed counter-current chromatography. J Sep Sci 29(11): 1653-1657.

9. Bruneton J (1995) Pharmacognosy, phytochemistry, medicinal plants. Laviosier Publishing, Paris, pp. 333.

10. Oyepata Simeon Joseph, Jude e Okokon, Opeyemi tosin Joseph (2018) Hepatoprotective activity of extract of Homalium Letestui stem against carbon tetrachloride-induced liver injury. Advanced Herbal Medicine 4(4): 1-11.

11. Khare CP (2004) Indian herbal remedies: Rational western therapy, Ayurvedic and other traditional usage, Botany. Springer, Berlin, pp. 451452 
12. Chang CL, Lin CS (2010) Development of antioxidant activity and pattern recognition of Terminalia chebulaRetzius extracts and its fermented products. Hung Kuang J 61: 115-129.

13. Naik GH, Priyadarsini KI, Naik DB, Gangabhagirathi R, Mohan H (2004) Studies on the aqueous extract of Terminalia chebula as a potent antioxidant and a probable radioprotector. Phytomedicine 11(6): 530538.

14. Mahesh R, Bhuvana S, Begum VM (2009) Effect of Terminalia chebula aqueous extract on oxidative stress and antioxidant status in the liver and kidney of young and aged rats. Cell Biochem Funct 27(6): 358-363.

15. Obatomi DK, Bikomo EO, Temple VJ (1994) Antidiabetic properties of African Mistletoe in streptozocin-induced diabetic rats. J Ethnopharmacol 43(1): 13-17.

16. Gunver SK, Renate G, Helmut K (2011) Safety of higher dosages of Viscum album L. in animals and humans - systematic review of immune changes and safety parameters. BMC Complementary and Alternative Medicine 11: 72 .

17. Joshi PK, Bose M, Harish D (2002) Haematological changes in the blood of Clarias battrachus exposed to mercuric chloride. Ecotoxicol Environ Monit 12: 119-122.

18. Sunmonu TO, Oloyede OB (2010) Performance and haematological indices in rats exposed to monocrotophos contamination. Hum Exp Toxicol 29(10): 845-850.

19. Okonkwo JE, Iyadi KC, Effiong CO (2004) Effect of chronic administration of haematological parameters of rats. Nig J Physiol Sc 19(1-2): 10-13.
20. McLellan SA, McLellan DBL, Walsh TS (2003) Anaemia and red blood cell transfusion in the critically ill patient. Blood Rev 17: 195-208.

21. Dacie JV, SM Lewis (2002) Practical Haematology. (11 $1^{\text {th }}$ edn), Elsevier, London, UK, pp: 380-382.

22. Eseyin OA, MA Sattar, HA Rathore (2014) A review of the pharmacological and biological activities of the aerial parts of Telfairia occidentalis Hook.f. (Cucurbitaceae). Trop J Pharmaceut Res 13(10): 1761-1769.

23. Fagbemi TNF, AF Eleyinmi, HN Atum, O Akpambang (2005) Nutritional composition of fermented fluted pumpkin (Telfairia occidentalis) seeds for production of ogiri ugu. Proceedings of the IFT Annual Meeting, New Orleans, Louisiana.

24. Baliah TY, Astalakshmi A (2014) Phytochemical analysis and antibacterial activity of extracts from. Int J Curr Microbiol App Sci 3(3): 992-999

25. Edeoga HO, Okwu DE, Mbaebie BO (2005) Phytochemical Constiuents of some Nigerian medicinal plants. Afri J Biotechnol 4 (7): 685-688.

26. Fedeyi MQ Adeoye AE, Olowokudejo JD (1989) Epidermal and phytochemical studies in genus Boerhavia (Nyctanginaceal) in Nigeria. Inter J Dcrude Drug Research 29: 178-184.

27. Vogel AI (1958) A Textbook of practical organic Chemistry. Longman, 99: 90-92.

28. Yang SW, Ubillas R, McAlpine J, Stafford A, Ecker DM, et al. (2001) Three new phanolic compounds from a manipulated plant cell culture mirabilis jalapa. J Nat Prod 64(3): 313-317. 